\title{
Melatonin and Hyaluronic Acid in Periodontal Disease
}

\author{
CORINA MARILENA CRISTACHE ${ }^{1}$, EUGENIA EFTIMIE TOTU²*, GHEORGHE CRISTACHE ${ }^{3}$, AURELIA CRISTINA NECHIFOR², \\ INGRID IOANA PINTILIE ${ }^{4}$ \\ ${ }^{1}$ Carol Davila University of Medicine and Pharmacy, Department of Dental Techniques, Faculty of Midwifery and Medical \\ Assisting (FMAM), 8 Eroilor Sanitari Blvd., 050474, Bucharest, Romania \\ UUniversity Politehnica of Bucharest, Faculty of Applied Chemistry and Material Science, 1-5 Polizu Str, 11061, Bucharest, \\ Romania \\ ${ }^{3}$ Concordia Dent Clinic, 7D-7E Vitan-Barzesti Str., 042122, Bucharest, Romania \\ ${ }^{4}$ Carol Davila University of Medicine and Pharmacy, Department of Removable Prosthodontics, Faculty of Dental Medicine, \\ 19 Plevnei Str., 010221, Bucharest, Romania
}

The aim of the present paper was to highlight the individual effects of melatonin (MEL) and hyaluronic acid (HA) on periodontal structures and repair mechanism and to investigate a possible synergic effect and if each component of the proposed mixture (MEL-HA) would maintain their specific characteristics, when using booth active principles, for a topical application. A comprehensive review of the recent literature focusing on the role of MEL and HA in periodontal therapy, as well as on the use of both active compounds and possible synergic effect, have been conducted. An experimental investigation, using the FT-IR analysis, both the individual spectra of each component and the complex matrix obtained was performed. The experimental data obtained from our study proved that no structural changes occurred at the level of the functional groups of the components. Therefore, it is expected that the obtained formulation to be highly efficient for the treatment of periodontal disease, as it would combine the specific local action of MEL and $H A$.

Keywords: Melatonin, hyaluronic acid, synergy, periodontal disease, FT-IR analysis

Periodontal disease is considered a multifactorial inflammatory condition, caused by the interaction between oral bacteria organized in complex communities that form biofilms [1], adhering to the dental structures and infecting the tooth supporting tissues, and the local host defense response [2]. Consequently, the junctional epithelium migrates apically with the destruction of connective tissue collagen fibers attachment and alveolar bone loss. Untreated, periodontal disease ultimate outcome is tooth loss [3,4]. The standard periodontal treatment consists of mechanical debridement to remove biofilm and calculus from the affected root surfaces, followed by antimicrobial therapy delivered either systemically or locally [5] and chemotherapeutical agents aiming to support the healing process by reducing inflammatory parameters such as bleeding on probing (BOP) and probing depth (PD) [6] The mostly used topical antimicrobial agents for periodontal disease treatment are chlorhexidine, tetracycline, minocycline and metronidazole $[7,8]$. Among the antiinflammatory chemotherapeutical agents, melatonin and hyaluronic acid became of a great interest lately, due to their physiological and structural functions and lack of toxicity.

A significant number of clinical studies were performed using either hyaluronic acid (HA) or melatonin (MEL) as adjunctive therapy after scaling and root planning (SRP) in periodontal compromise patients. But the effect of combining MEL and HA in a complex active compound was insufficient investigated $[9,10]$.

Therefore, the aim of the present paper was to highlight the individual effects of MEL and HA on periodontal structures and repair mechanism and to investigate a possible synergic effect and if each component of the proposed mixture (MEL-HA) would maintain their specific characteristics, when using booth active principles, for a topical application.

\section{Experimental part}

A comprehensive review of the recent literature focusing on the role of MEL and HA in periodontal therapy, as well as on the use of both active compounds and possible synergic effect, have been performed. The following databases: Pubmed, Summon database - ProQuest, Embase, Cochrane have been assessed for articles in English language, from 1960 to date. A manual search in Periodontology 2000, J ournal of Periodontology, Revista de Chimie, J ournal of Dentistry, Revista de Materiale Plastice and Dental Materials, has been also performed.

An attractive pharmaceutical combination of MEL and $H A$, with possible applications for in dentistry has also been experimentally studied.

\section{Materials}

To achieve the various combinations of the proposed complex material, HA solutions (HA reference standard, USP) were used at concentrations ranging from 1-4 mg/ $\mathrm{mL}$. The solutions were obtained in deionized water (conductivity $128 \mu \mathrm{S} / \mathrm{cm}^{2}$ ). Fresh melatonin solutions (MEL-Sigma-Aldrich), $3 \mathrm{mg} / \mathrm{mL}$ in methanol (Merck) were obtained. Taking into account the ultimate goal of our studies, namely to develop treatment for periodontal lesions, specific amounts of MEL and HA were taken to prepare the MEL - HA composition. The MEL-HA mixture was prepared by melatonin initially dissolving and then adding hyaluronic acid. For homogenization, the mixture was kept for one hour in a thermostatically controlled ultrasonic bath $\left(25^{\circ} \mathrm{C}\right)$. Subsequently, the prepared mixture was stored in a dark and cold place until complete removal of the air bubbles resulting from the mixing of the HA solution. The solution thus obtained has been used for complex structural investigations.

Such homogeneous composition can be applied topically inside the periodontal pocket without any particular problems.

\footnotetext{
* email: eugenia totu@yahoo.com
} 
Investigation methods

The structural changes of the new material's components have been investigated with FTIR techniques. The FTIR spectroscopyallows the detection of components of complex mixtures of biologically active compounds. Thus, samples can be differentiated by identifying chemical compositions of molecules or macromolecules in complex biological samples under observation [11]. In order to perform FT-IR determinations, it was no longer necessary to prepare the samples in $\mathrm{KCl}$ due to the use of sphere (reflective attenuation), ATR equipment. FT-IR determinations for solid samples have been performed on a Brucker Tensor 27 (ATR) equipment over a spectral range of $4000-500 \mathrm{~cm}^{-1}$. The spectral resolution was $4 \mathrm{~cm}^{-1}$. The background spectrum was performed on each scan. The data obtained were processed using the OPUS NT 7.0 software (Brucker Optics, Germany).

\section{Results and discussions}

Melatonin (MEL), discovered and isolated by Lerner in 1958 , is a natural hormone produced mainly by the pineal gland but also by other tissues and organs, such as the retina, brain, bone marrow, Harderian gland, ciliary body, lens, thymus, airway epithelium, gonads, placenta, gastrointestinal tract and skin, in a circadian manner, with the highest level during the night (between midnight and 2 a.m. for healthy adults) and a minimum during the day [12-14]. MEL is an indole amine (N-acetyl-5-methoxytryptamine) with important roles in regulating physiological and pathological processes by binding to its membrane receptors (MT1 and MT2) as well as its nuclear receptors (RZR/ROR) [9,15].

Most of the circulating MEL derives from the pineal cells, where is synthetized from its precursor, serotonin by the sequential action of arylalkylamine $\mathrm{N}$-acetyltransferase and hydroxyindole-0-methyltransferase [16]. MEL can be degraded via indolic and kynuric pathways and excreted in urine [17]

\section{Biological actions}

As natural hormone, MEL has numerous physiological functions in different parts of the body, such as regulating the circadian rhythms [18], modulating body temperature, activating of the immune system, also an important antioxidant and an anti-inflammatory role by reducing oxidative stress: directly by scavenging reactive oxygen and nitrogen species and indirectly by stimulating antioxidant enzymes while suppressing pro-oxidant ones $[19,20]$. It also exhibits anti-angiogenic effects on endothelial cells [21] and plays an important role in bone formation and in the reduction of bone resorption [22].

$M E L$, as well as some synthetic analogs, can be therapeutically administrated (systemic or topic) for the treatment of various conditions such as sleep disorders, diabetes, metabolic and cardiovascular diseases, Parkinson, affective disorders, chronic inflammatory diseases and cancer, among others [13].

\section{The use of MEL in periodontal therapy}

MEL diffuses passively into saliva from the systemic circulation, with the salivary MEL concentration representing $24-33 \%$ of its plasma levels, ranging from 1 to $5 \mathrm{pg} / \mathrm{mL}$ during daytime to $50 \mathrm{pg} / \mathrm{ml}$ after midnight peak [13]. Several studies reported that salivary MEL levels were significantly reduced in subjects with periodontal disease, especially in chronic and aggressive periodontitis [23-25], with the recovering of the decreased salivary level after periodontal treatment [24]. Therefore, salivary MEL could act as a diagnostic biomarker in periodontal disease [26] .
Topical administration of MEL, $1 \%$ orabase cream formula, prepared by the Department of Hospital Pharmacy of Hospital Perpetuo Socorro (Granada, Spain) was used for 20 days as treatment for patients with diabetes affected by periodontal disease [27-29]. The results were promising, topical use of MEL in diabetic patients improved clinical periodontal parameters ( gingival index and pocket depth) and reduced phosphatase, osteopontin and osteocalcin levels [29], reduced RANKL/ osteoprotegrin ratio [27] and as well as serum levels of C-reactive protein, interleukin- 6 and tumor necrosis factor-alpha levels [28], improving the quality of alveolar bone and preventing the progression of periodontal disease.

Systemic MEL supplement (10 mg oral MEL capsule once daily before bedtime) administrated for 2 months for patients with insomnia, in conjunction with scaling and root planning (SRP) yield to significantly greater clinical attachment level gain and periodontal pocket depth reduction and also lower salivary tumor necrosis factoralpha levels comparing to placebo [30]. Favorable results on periodontal parameters have been also obtained after SRP with an adjunctive dose of MEL ( $2 \mathrm{mg}$ a day for 4 weeks) and vitamin C (60 mg for females and $75 \mathrm{mg}$ for males for 4 weeks) comparing to SRP alone [31].

Hyaluronic acid (HA), also known as hyaluronan, discovered in 1934 and first isolated from the vitreous humor of cow's eyes by Mayer and Palmer, is a linear polyanion, with a poly repeating disaccharide structure $[(1 \rightarrow 3)-\beta$-d-GICNAc$(1 \rightarrow 4)-\beta-d-G l c A-]$ [32], not synthesized in Golgi apparatus as the other endogens glycosaminoglycans. In natural environment, HA occurs in the salt form, hyaluronate, and is found in different molecular weight, namely high (HMW) and low molecular weight (LMW), conditioning the physiological effects. However, a definition of HMW and LMW is not clear in the literature, most of the authors agreeing with $\mathrm{HMW} \geq 10^{6} \mathrm{Da}$ and $\mathrm{LMW}<10^{6} \mathrm{Da}[33,34]$.

$H A$ is naturally found in the extracellular matrix of connective tissue, skin, synovial fluid, vitreous humor, umbilical cord and many others organs and tissues of the body, the total content is $15 \mathrm{~g}$ for a 70-kg adult [35]. It has been identified in all periodontal tissues, mostly in the nonmineralized tissues such as gingiva and periodontal ligament and, in low quantities in mineralized tissues such as cementum and alveolar bone $[7,36]$.

Synthesis of natural $\mathrm{HA}$ is performed at the inner surface of the plasma membrane by 3 different but related enzymes, hyaluronan synthases (HAS), HAS1, HAS2 and HAS3, located on different chromosomes, producing HA with different molecular weights [37]. In general, HAS3 synthesized the shortest HA polymer sizes $\left(1 \times 10^{5}\right.$ to $1 \times$ $10^{6} \mathrm{Da}$ ), while HAS1 and HAS2 synthesized larger polymers $\left(2 \times 10^{5}\right.$ to $\left.2 \times 10^{6} \mathrm{Da}\right)$ [38]. The HMW HA present in periodontal tissues is synthesized by HAS1 and HAS2 in periodontal tissues cells: fibroblasts and keratinocytes in gingiva and periodontal ligament, cementoblasts in cementum and osteoblasts in alveolar bone [39].

Degradation of HA in the human body is performed by two different mechanisms: specific, mediated by the hyaluronidase enzymatic complex and non-specific, mediated by reactive oxygen species (oxidative damage) [40].

\section{Biological actions}

HMW and LMW HA can display opposite effects, even when they are simultaneously present in a specific tissue [34].

Extracellular HMW HA is anti-angiogenic, inhibits endothelial cell growth, it binds fibrinogen, reduces the 
recruitment of inflammatory cells, the levels of inflammatory cytokines and the migration of stem cells. Beside its anti-inflammatory effect, HMW HA has a beneficiary role in tissue injury repair, wound healing and immunosuppression [41,42]. On the other site, LMW HA has been shown to possess pro-inflammatory and proangiogenic activities, stimulating the production of proinflammatory cytokines, chemokines and growth factors [34] and to promote ectodermal matrix remodeling, and also being able, in certain conditions, to induce tumor progression [43].

Two basic mechanisms are responsible for the HA biological actions, both depending upon molecules size: the passive mechanism, related to the physico-chemical properties, macromolecular size, hygroscopicity and viscoelasticity, with major role in modulating tissue hydration and osmotic balance of the ectodermal matrix [44], and the active mechanism, as signaling molecules, by interacting with its binding proteins $[34,40]$.

\section{The use of HA in periodontal therapy}

$\mathrm{HA}$ play a regulatory role in inflammatory response of the periodontal tissues: HMW is fragmented to LMW molecules under the influence of reactive oxygen species, including the superoxide radical and hydroxyl radical species primarily generated by infiltrating polymorphonuclear leukocytes and other inflammatory cells during bacterial phagocytosis [17]. LMW fragments are involved in signaling tissue damage and mobilizing immune cells, while the HMW-HA suppresses the immune response preventing excessive exacerbations of inflammation [12].

The first successful use for periodontal disease topical treatment was proved by Pagnacco and co-workers in 1997, in a clinical trial vs placebo, exploring the antiinflammatory, anti-edematous, and anti-bacterial effects of HA [45]. Moreover, high level of natural HA are present in serum all fluid samples examined of gingival crevicular fluid (GCF), regarded as a serum-derived product, but absent in GCF samples from patients with acute necrotizing ulcerative gingivitis [10]. It reappears after effective antibacterial treatment with consequently reducing the bacterial hyaluronidase activity [11], proving that HA could be considered as marker for active disease [12].

Subgingival application of HA after full mouth SRP in chronic periodontis had beneficial effect observed, in several clinical studies, with overall improvements of periodontal tissues health [36]. Statistically significant reduction of $B O P$ and $P D$, as compared to control was observed by ohannsen and co-workers, Polepalle and coworkers [46] and Al-Shammari and co-workers [47], after professional subgingival application of $0.8 \% \mathrm{HA}$ gel, on patients with chronic periodontitis. Similar results were obtained by Rajan et al. [48], Sahayata et al. [49], Xu et al. [50], Gontiya and Galgali using $0.2 \%$ HA. Furthermore, after gingival biopsies evaluation, Mesa and co-workers [51] and Gontiya and Galgali [52] concluded that high molecularweight HA gel reduces cell proliferation in epithelial cells such as fibroblasts and lymphocytes, diminishing the inflammatory process at periodontal tissues level.

Eick and co-workers [53] revealed reduction on recolonization by periodontopathogens (such as Campylobacter, Prevotella intermedia, and Porphyromonas gingivalis) after SRP and subgingival administration of a gel containing $0.8 \% \mathrm{HA}$ ( $18 \times 105 \mathrm{Da}$ ) with addition of topical application of $0.2 \% \mathrm{HA}$ (105Da), twice daily for 14 days, when comparing to the control group (SRP only). Experimental evaluation of MEL and HA synergy
Using the FT-IR analysis, both the individual spectra of each component and the complex matrix obtained were studied.

MEL (having the structural formula shown in fig. 1.a) is a substance having a high $\log \mathrm{P}$ partition coefficient of 1.2 [54], and preferentially localizes at hydrophilic / hydrophobic interfaces thus leading to the phospholipids' disordonation at the asymmetric stretch extent of the bonds of $-\mathrm{CH}_{2}$ and the hydrogen bonding between the extended carbonyl bonds and the phosphate anion $[55,56]$ group. The melatonin FT-IR spectrum(fig. 2.a), shows the major bands for functional groups at 3306 and $3260 \mathrm{~cm}^{-1}$ (bending vibrations for $\mathrm{NH}$ and $\mathrm{CN}$ stretching), 1492 and $1550 \mathrm{~cm}^{-1}$ (vibration for $\mathrm{C}=\mathrm{C}$ aromatic), $1630 \mathrm{~cm}^{-1}(\mathrm{C}=0$ bond vibration), 1180 and $1217 \mathrm{~cm}^{-1}$ (V-bond vibration). These experimental data are in agreement with previous studies $[57,58]$.

The FTIR results of complex formulation showed the specific patterns of each compound.

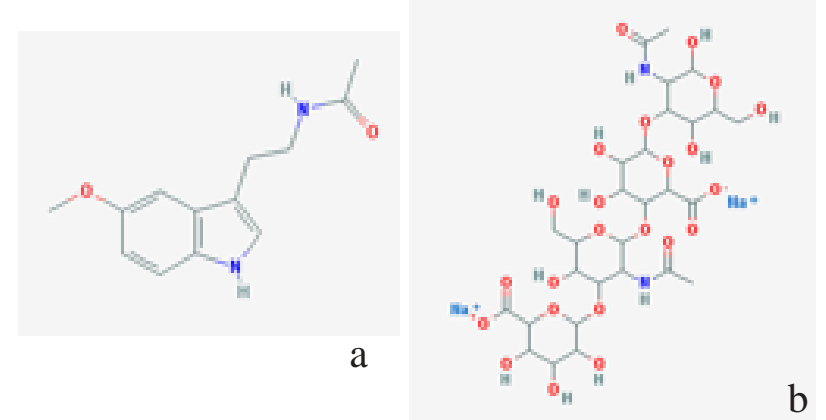

Fig, 1. Individual components structure a. melatonin structure. $b$. hyaluronic acid structure

In figure $2 b$ the FT-IR spectra of hyaluronic acid, Figure 1.b., highlights the $\mathrm{N}-\mathrm{H}$ from the amide group on the region between 3200-3600 $\mathrm{cm}^{-1}$; an amide band at 1595-1710 $\mathrm{cm}^{-1}$ appears to be attributable to the extent of $\mathrm{C}=0$ and the bending of $\mathrm{N}-\mathrm{H}$. It is also a specific band for bending $\mathrm{C}$ $\mathrm{H}_{2}$ in the region $1350-1480 \mathrm{~cm}^{-1}$ and the extent of $\mathrm{C}-0$ in the proteoglycan cycle occurs between $985-1140 \mathrm{~cm}^{-1}$.
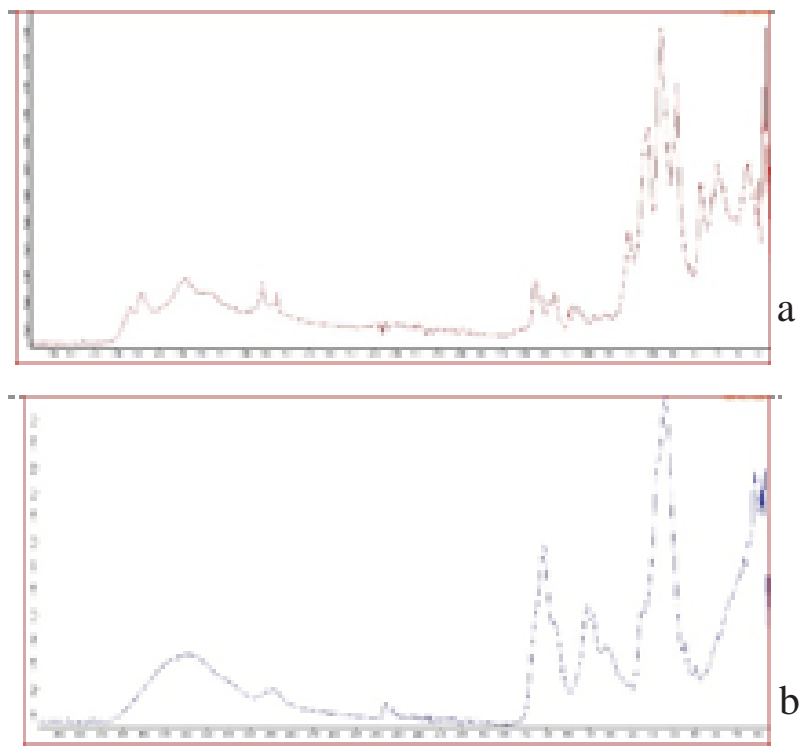

Fig. 2. FT-IR spectra for individual compounds. a. melatonin, b. hyaluronic acid

Qualitative analysis of individual FT-IR spectra for each component: melatonin, hyaluronic acid allows the identification of characteristic absorption bands. The FTIR spectrum of the physical mixture: hyaluronic acid and 


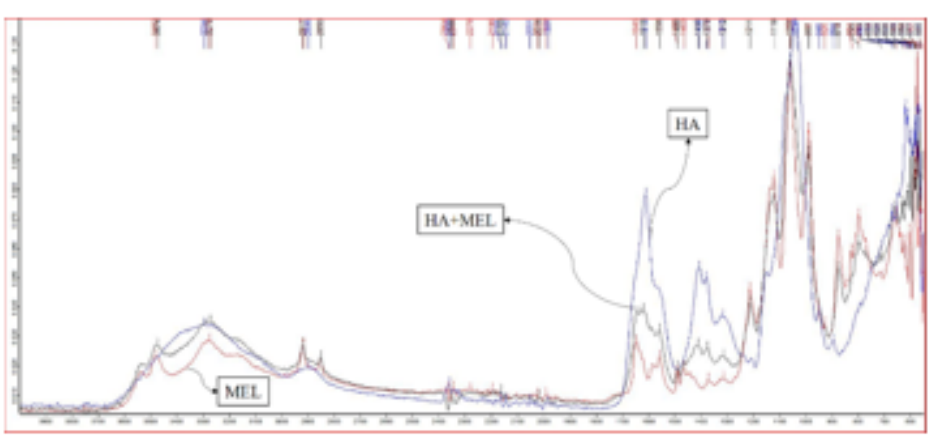

Fig. 3. FTIR spectrum of mixture: hyaluronic acid and melatonin

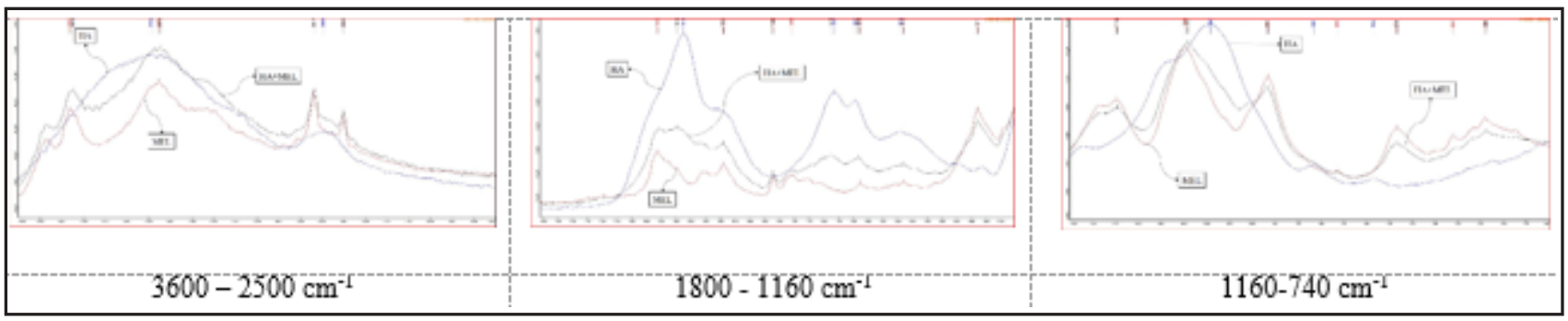

Fig. 4. Detailed FTIR spectra for mixture melatonin - hyaluronic acid

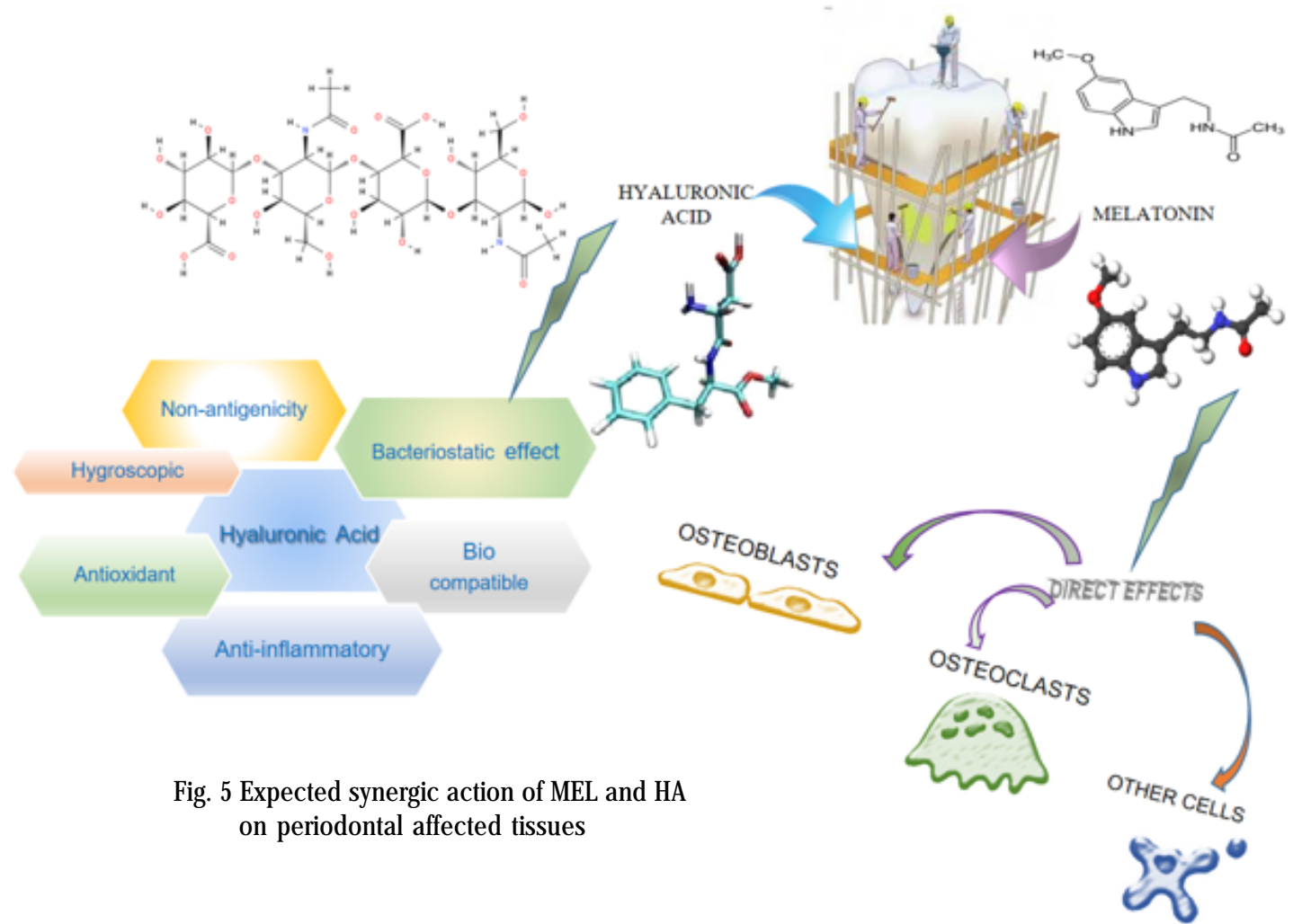

melatonin, presented in figure 3 , shows absorption bands in the same regions in agreement with the functional groups identified in the individual spectra (fig. 2).

The detailed investigation of the FTIR spectrum for the mixture (melatonin and hyaluronic acid), as presented in figure 4, highlight the presence of the specific absorption bands for each component.

It is evident that by achieving a complex matrix of the two compounds, a single spectrum is obtained that practically combines the prominent absorption bands for each individual component. Thus, it is confirmed that there are no interactions between the medicinal products used to obtain the complex matrix [9] and therefore a synergic action of them it is expected (fig. 5).

\section{Conclusions}

A significant number of positive effects of MEL, as well as $\mathrm{HA}$, as individual compounds on the periodontium and potential therapeutic roles have been documented in literature. The experimental data obtained from our study proved that no structural changes occurred at the level of the functional groups of the components. Therefore, it is expected that the obtained formulation to be highly efficient for the treatment of dental wounds, as it would combine the specific local action of MEL and HA. How ever, well designed clinical studies are required to ascertain the use of the newly obtained complex mixture in the clinical setting.

Acknowledgement: This work was supported by a grant of the Romanian National Authority for Scientific Research and Innovation, CCCDI - UEFISCDI, project number 30/2016 (ERA-NET-MANUNET II) within PNCDI III and partially supported by a grant of the Romanian National Authority for Scientific Research and Innovation, CCCDI UEFISCDI, projectnumber 39/2018COFUND-MANUNET III-HAMELDENT, within PNCDI III. 


\section{References}

1. MARSH, P., D., ZAURA, E., J. Clin. Periodontol., Suppl 18, 2017, S12S22.

2. ELASHIRY, M., MEGHIL, M., M., ARCE, R., M., CUTLER, C., W., J. Periodontal Res. 54, no.1, 2019, p.1.

3. COSTA, F., O., LAGES, E., J., P., COTA, L., O., M., LORENTZ, T., C., M., SOARES, R., V., CORTELLI, J., R., J. Periodontal Res., 49, no.1, 2014, p.121.

4. VELEA, O., A., SINESCU, C.,ZEICU, C., FREIMAN, P., C., VELEA, P., I., ONISEI, D., DUMA, V., F., Rev. Chim.(Bucharest), 65, no.9, 2014, p.1063. 5. JEPSEN, K., JEPSEN, S., Periodontol. 2000, 71, 2016, p.82.

6. MUELLER, A., FUJIOKA-KOBAYASHI, M., MUELLER, H., D., LUSSI, A., SCULEAN, A., SCHMIDLIN, P., R., MIRON, R., .J. Clin. Oral Investig., 21, no.4, 2017, p.1013.

7. DAHIYA, P., KAMAL, R., MANI, A., N Am J Med Sci., 5, no.5, 2013, p.309.

8. BONITO, A., J., LUX, L., LOHR, K., N., J Periodontol, 76, 2005, p.1227.

9. CRISTACHE, C., M., TOTU, E., E., PETRE, D., BUGA, R., CRISTACHE, G., TOTU, T., Rev. Chim.(Bucharest), 69, no.8, 2018, p.1996.

10.TUNCAY TANRIVERDI, S., CHEABURU-YILMAZ, C., N., CARBONE, S., OZER, O., Pharm. Dev. Technol., 23, no.8, 2018, p.815.

11.TOTU, E., E., RUSE, E., GARDEA, R., GRIGORESCU, A., Optoelectron. Adv. Mater., 2, no.7, 2008, p.442.

12. CHOWDHURY, I., SENGUPTA, A., MAITRA, S., K., Indian J Biochem Biophys., 45, no.5, 2008, p.289.

13. CARPENTIERI, A., R., PERALTA LOPEZ, M., E., AGUILAR, J., SOLA, V., M., Pharmacol. Res., 125, 2017, p.224.

14. SIMONNEAUX, V., Pharmacol. Rev., 55, no.2, 2003, p. 325.

15. SLOMINSKI, R., M., REITER, R., J., SCHLABRITZ-LOUTSEVITCH, N., OSTROM, R., S., SLOMINSKI, A., T., Mol. Cell. Endocrinol., 351, 2012, p.152.

16. AXELROD, J., Science., 184, no.4144, 1974, p.1341.

17. MA, X., IDLE, J., R., KRAUSZ, K., W., GONZALEZ, F., J., Drug Metab. Dispos., 33, no.4, 2005, p.489.

18. CARPENTIERI, A. R., OLIVA, C., DIEZ-NOGUERA, A., CAMBRAS, T., Chronobiol Int., 32, no.7, 2015, p.994.

19. REITER, R., J., MAYO, J., C., TAN, D., X., SAINZ, R., M., ALATORREJIMENEZ, M., QIN, L., J. Pineal Res., 61, no.3, 2016, p.253.

20. CRISTACHE, C., M., GROSU, A., R., CRISTACHE, G., DIDILESCU, A., C., TOTU, E., E., Mat. Plast., 55, no.4, 2018, p.555.

21. ALVAREZ-GARCIA, V., GONZALEZ, A., ALONSO-GONZALEZ, C., MARTINEZ-CAMPA, C., COS, S., Microvasc. Res., 87, 2013, p.25.

22. PERMUY, M., LOPEZ-PENA, M., GONZALEZ-CANTALAPIEDRA, A., MUNOZ, F., Int. J. Mol. Sci., 18, no.4, 2017, p.E865.

23. ALMUGHRABI, O., M., MARZOUK, K., M., HASANATO, R., M., SHAFIK, S., S., J. Periodontal Res., 48, no.3, 2013, p.315.

24. BERTL, K., SCHOIBER, A., HARIRIAN, H., LAKY, M., STEINER, I., RAUSCH, W., D., ANDRUKHOV, O., RAUSCH-FAN, X., Clin. Oral Investig., 17, 2013, p.1219.

25. CUTANDO, A., GALINDO, P., GOMEZ-MORENO, G., ARANA, C., BOLANOS, J., ACUNA-CASTROVIEJ O, D., WANG, H., L., J. Periodontol., 77, no.9, 2006, p.1533.

26. TOTHOVA, L., KAMODYOVA, N., CERVENKA, T., CELEC, P., Front. Cell. Infect. Microbiol., 5, 2015, Art.73.

27. CUTANDO, A., LOPEZ-VALVERDE, A., GOMEZ-DE DIEGO, R., DE VICENTE, J., REITER, R., HERRERO FERNANDEZ, M., FERRERA, M., J., Odontology, 102, no.2, 2014, p.290.

28. CUTANDO, A., MONTERO, J., GOMEZ-DE DIEGO, R., FERRERA, M., J., LOPEZ-VALVERDE, A., J. Clin. Exp. Dent., 7, no.5, 2015, e6282015. 29. CUTANDO, A., LOPEZ-VALVERDE, A., GOMEZ-DE-DIEGO, R., ARIASSANTIAGO, S., DE VICENTE-JIMENEZ, J., Med. Oral Patol. Oral Cir. Bucal, 18, no.4, 2013, p.e6572013.
30. EL-SHARKAWY, H., ELMEADAWY, S., ELSHINNAWI, U., ANEES, M., J. Periodontal Res., 54, no.2, 2019, p.190.

31. CHITSAZI, M., FARAMARZIE, M., SADIGHI, M., SHIRMOHAMMADI, A., HASHEMZADEH, A., J Dent Res Dent Clin Dent Prospects., 11, no.4, 2017, p.236.

32. NECAS, J., BARTOSIKOVA, L., BRAUNER, P., KOLAR, J., Vet. Med. (Praha)., 53, 2008, p.397.

33. TAKEDA, K., SAKAI, N., SHIBA, H., NAGAHARA, T., FUJ ITA, T., KAJIYA, M., IWATA, T., MATSUDA, S., KAWAHARA, K., KAWAGUCHI, $\mathrm{H}_{\text {, }}$ KURIHARA, H., Tissue Eng. - Part A, 17, no.7-8, 2011, p.955.

34. CYPHERT, J., M., TREMPUS, C., S., GARANTZIOTIS, S., Int. J. Cell Biol., 563818, 2015.

35. VOLPI, N., SCHILLER, J., STERN, R., SOLTES, L., Curr. Med. Chem., 16, no.14, 2009, p.1718.

36. CASALE, M., MOFFA, A., VELLA, P., SABATINO, L., CAPUANO, F., SALVINELLI, B., LOPEZ, M., A., CARINCI, F., SALVINELLI, F., Int. J. Immunopathol. Pharmacol., 29, no.4, 2016, p.572.

37. LEE, J. Y., SPICER, A., P., Curr. Opin. Cell Biol., 12, no.5, 2000, p.581.

38. ITANO, N., SAWAI, T., YOSHIDA, M., LENAS, P., YAMADA, Y., IMAGAWA, M., SHINOMURA, T., HAMAGUCHI, M., YOSHIDA, Y., OHNUKI, Y., MIYAUCHI, S., SPICER, A., P., MCDONALD, J., A., KIMATA, K., J. Biol. Chem., 274, no.35, 1999, p.25085.

39. IJUIN, C., OHNO, S., TANIMOTO, K., HONDA, K., TANNE, K., Arch. Oral Biol., 46, no.8, 2001, p.767.

40. FALLACARA, A., BALDINI, E., MANFREDINI, S., VERTUANI, S., Polymers (Basel), 10, no.701, 2018.

41. JIANG, D., LIANG, J., NOBLE, P., W., Annu. Rev. Cell Dev. Biol., 23, 2007, p.435.

42.JIANG, D., LIANG, J., NOBLE, P., W., Physiol. Rev., 91, no.1, 2011, p.221.

43. WU, M., CAO, M., HE, Y., LIU, Y., YANG, C., DU, Y., WANG, W., GAO, F., FASEB J., 29, no.4, 2015, p.1290.

44. ROBERT, L., ROBERT, A., M., RENARD, G., Pathol Biol (Paris), 58, no.3, 2010, p.187.

45. PAgnaCCO, A., VANGelisti, R., ERRA, C., POMA, A., Attual. Ter. Internazionale, 15, 1997, p.1.

46. POLEPALLE, T., SRINIVAS, M., SWAMY, N., ALURU, S., CHAKRAPANI, S., CHOWDARY, B.,A., J Indian Soc Periodontol., 19, no.1, 2015, p.37. 47. AL-SHAMMARI, N.,M., SHAFSHAK, S.,M., ALI, M.,S., J Contemp Dent Pract., 19, no.5, 2018, p.527.

48. RAJ AN, P., BARAMAPPA, R., RAO, N.,M., PAVALURI, A.,K., RAHAMAN, S.,M., J Clin Diagn Res., 8, no.12, 2014, p.ZC11.

49. SAHAYATA, V., N., BHAVSAR, N., V., BRAHMBHATT, N., A., Oral Health Dent. Manag., 13, no.3, 2014, p.779.

50. XU, Y., HOFLING, K., FIMMERS, R., FRENTZEN, M., J ERVOE-STORM, P., J. Periodontol., 75, no.8, 2004, p.1114.

51. MESA, F., L., ANEIROS, J., CABRERA, A., BRAVO, M., CABALLERO, T., REVELLES, F., DEL MORAL, R., G., O'VALLE, F., Histol Histopathol, $17,2002, \mathrm{p}-747$.

52. GONTIYA, G., GALGALI, S.,R., J Indian Soc Periodontol., 16, no.2, 2012, p.184.

53. EICK, S., RENATUS, A., HEINICKE, M., PFISTER, W., STRATUL, S., JENTSCH, H., J. Periodontol., 84, no.7, 2013, p.941.

54. EL-GINDY, A., EL WALILY, A., F., M., BEDAIR, M., F., J. Pharm. Biomed. Anal., 23, no.2-3, 2000, p.341.

55. KIKWAI, L., KANIKKANNAN, N., BABU, R., J ., SINGH, M., J . Control. Release, 83, 2002, p.307.

56. EPSTEIN, F., H., BRZEZINSKI, A., N. Engl. J. Med., 336, 1997, p.186. 57. JAYACHANDRA BABU, R., DAYAL, P., P., PAWAR, K., SINGH, M., J. Drug Target., 20,no.3, 2012, p.731.

58. ARENDT, J., Rev Reprod., 3, no.1, 1998, p.13.

Manuscript received: 21.08 .2018 